\title{
MIASTO, REGION I TOŻSAMOŚĆ GEOGRAFII W ZAINTERESOWANIACH NAUKOWYCH PROF. DR. HAB. ANDRZEJA SULIBORSKIEGO
}

\section{Wprowadzenie}

Prof. dr hab. Andrzej Suliborski od początku pracy zawodowej związany jest z Uniwersytetem Łódzkim. W latach 2007-2016 pełnił funkcję kierownika, najpierw samodzielnego Zakładu, a następnie Katedry Geografii Regionalnej i Społecznej. Od początku pracy naukowej, dydaktycznej i organizacyjnej zainteresowania Profesora koncentrowały się na problematyce miejskiej oraz regionalnej w geografii, co znajdowało wyraz w podejmowanych badaniach, w tym związanych z awansem zawodowym, prowadzonych zajęciach dla studentów oraz na rzecz szeroko pojętej praktyki. Szerokie zainteresowania prof. A. Suliborskiego prowadziły również do podjęcia zagadnień teorii i metodologii geografii. Temat pracy magisterskiej i specjalizacja Zakładu Geografii Ekonomicznej, w którym wówczas pracował, ukierunkowały jego zainteresowania naukowe na geografię miast jako główną dziedzinę badań. Drugim nurtem badań była geografia regionalna (społeczno-ekonomiczna), a później także edukacja regionalna, z którymi wiązały go tradycje ich uprawiania przez prof. Ludwika Straszewicza, prof. Jana Dylika, oraz w zakresie edukacji prof. Annę Dylikową i doc. Zdzisława Batorowicza. Trzeci kierunek w pracy naukowej A. Suliborskiego odnosił się do teorii i metodologii geografii. Zainteresowania tą tematyką wyrazily się w postaci wielu artykułów, monografii oraz w inicjatywie i organizacji wraz z koleżanką z Katedry prof. Krystyną Rembowską i prof. Wiesławem Maikiem z Uniwersytetu Mikołaja Kopernika w Toruniu i Wyższej Szkoły Gospodarki w Bydgoszczy, cyklicznych seminariów teoretyczno-metodologicznych pt. Podstawowe idee i koncepcje w geografii. 


\section{Dorobek w zakresie geografii miast}

Głównym kierunkiem badań naukowych A. Suliborskiego jest geografia miast (osadnictwa miejskiego). Podstawę dla studiowania tej problematyki stanowiły wieloletnie doświadczenia zdobyte w trakcie prac terenowych. Od początku pracy naukowo-dydaktycznej A. Suliborski miał bardzo dobre możliwości prowadzenia takich badań, kierując po doktoracie ćwiczeniami terenowymi dla studentów geografii oraz biorąc udział w pracach naukowo-badawczych na rzecz gospodarki. W badaniach z zakresu geografii miast interesowały go dwa główne zagadnienia: - przestrzenne struktury społeczno-gospodarcze miasta, ich organizacja i funkcjonowanie oraz oddziaływania lokalne i regionalne miast,

- systemy miejskie (osadnicze), ich zróżnicowanie i ewolucja funkcjonalna.

Zainteresowania A. Suliborskiego problematyką wnętrza miasta, jego genezą oraz zróżnicowaniem morfologicznym, funkcjonalnym i społecznym zapoczątkowane zostały tematyką pracy magisterskiej. Zaangażowanie w jej realizację wiązało się z chęcią uzyskania pełnej wiedzy o przedmiocie oraz miało podłoże emocjonalne, ponieważ w osiedlu tym urodził się i mieszka do tej pory. Położone nad niewielką rzeczką osiedle Julianów, którego początki zabudowy mieszkaniowej przypadają na lata 20. ubiegłego wieku, stanowiło doskonałe pole badań geograficznych. Bezpośrednim opiekunem i nauczycielem podstaw pracy badawczej był wówczas dr Stanisław Pączka, nieżyjący już dzisiaj dr hab., prof. UŁ i wieloletni dyrektor Instytutu Geografii Ekonomicznej i Organizacji Przestrzeni. Wzorce metodologiczne czerpał z badań morfogenetycznych prowadzonych w Zakładzie Geografii Ekonomicznej przez ówczesnego dr. Marka Kotera.

Przemyślenia dotyczące sposobów badań struktury przestrzeni miejskiej zostały ugruntowane w trakcie prowadzonych przez zespół pracowników Zakładu Geografii Ekonomicznej UŁ studiów inwentaryzacji urbanistycznej miast województwa opolskiego i kieleckiego. W studiach tych A. Suliborski zajmował się szeroko rozumianym mieszkalnictwem. Problematyka ta w polskiej geografii - wówczas pionierska (lata 70. XX w.), rozwijana była w Zakładzie Geografii Ekonomicznej głównie przez dr. Jerzego Dzieciuchowicza. Osiągnięcia A. Suliborskiego w tym zakresie dotyczą opracowania oryginalnej koncepcji pojęcia „środowisko mieszkaniowe" (wewnętrzne i zewnętrzne) oraz założeń metodycznych jego badań (artykuł pt. Środowisko mieszkaniowe miasta jako przedmiot badań geografii osadnictwa, 1972). Była to pierwsza w geografii polskiej próba sformułowania koncepcji kompleksowego ujęcia środowiska mieszkaniowego miasta.

A. Suliborski prowadził również studia nad organizacją przestrzeni miejskiej i jej funkcjonowaniem. Były to studia nad strukturą przestrzenną osiedla mieszkaniowego, wiejskiego układu osadniczo-historycznego w górach Sierra Nevada w Hiszpanii, organizacją przestrzenną stosunków wielkościowych i własnościowych działek, a także funkcjonowaniem systemów usługowych i produkcyj- 
nych. Ważnym osiągnięciem metodycznym w tym zakresie było opracowane pod kierunkiem A. Suliborskiego studium struktury przestrzennej miasta Sieradza. Stanowi ono próbę przedstawienia monograficznej syntezy geograficzno-ekonomicznej miasta - zarówno zróżnicowanie przestrzeni miejskiej, jej genezę i organizację funkcjonalną, jak i oddziaływanie miasta i jego powiązania w układzie lokalnym, regionalnym i krajowym. Innym miastem regionu łódzkiego, któremu A. Suliborski poświęcił badania był Uniejów. Wówczas, jeden z najmniejszych ośrodków lokalnych w regionie łódzkim. Były to studia, które zostały opublikowane w bardzo obszernej monografii historycznej tego miasta.

Łódź, jej przestrzeń i region miejski, gospodarka, mieszkańcy od początku kariery naukowej stanowiły zawsze przedmiot jego studiów naukowych. Były to badania o charakterze społecznym, takie jak: znaczenie społeczne nekropolii łódzkich, rola i znaczenie łódzkich przedsiębiorców w procesie zmiany gospodarczej, czy funkcjonowanie i rola rad osiedlowych w przestrzeni miejskiej, czy też szersze studia poświęcone czynnikom, mechanizmom i skutkom powstających w mieście dysproporcji społecznych i gospodarczych. W wymiarze regionalnym były to badania odnoszące się do metropolii łódzkiej - jej problemom integracji społeczno-gospodarczej i funkcjonalnej. Znaczącym osiągnięciem naukowym A. Suliborskiego są opracowane, we współautorstwie z prof. Aleksandrą Jewtuchowicz, rozdziały dotyczące gospodarki oraz życia społecznego i kulturalnego w obszernej monografii miasta Łodzi, wydanej również w wersji anglojęzycznej. Niewątpliwie znaczącym wyzwaniem intelektualnym było uczestniczenie w opracowaniu koncepcji atlasu Łodzi, redakcja czterech plansz oraz współautorstwo zamieszczonych na nich map.

Relacje między miastem a otaczającą go najbliższą i dalszą przestrzenią społeczno-gospodarczą A. Suliborski badał przez identyfikację przestrzenną różnych funkcji egzogenicznych oraz związki społeczne (demograficzne) miasta z jego otoczeniem. Badania takie prowadził na przykładzie takich miast, jak: Nysa, Sieradz, Humenne w Słowacji czy Łódź. Stanowiły one empiryczną podstawę do prowadzenia rozważań teoretycznych nad pojęciami aglomeracji wielkomiejskiej i strefy podmiejskiej.

Wszystkie artykuły z tej problematyki w swojej istocie odnoszą się przede wszystkim do empiryczno-teoretycznego rozpoznania funkcji regionalnych (lokalnych) miast i mieszczą się w szeroko pojętej problematyce funkcjonalnej, która wyrasta z tradycji i dokonań łódzkiej szkoły geografii społeczno-ekonomicznej. A. Suliborski kontynuując i rozwijając badania funkcjonalne nad systemami miejskimi niewątpliwie stał się bardzo ważnym przedstawicielem tego nurtu w Polsce, wybitnym znawcą problematyki przemian funkcji i struktury funkcjonalnej osadnictwa.

Swoje badania w tym zakresie rozpoczął pracą doktorską na temat zmian funkcji miast w regionie łódzkim, wykorzystując do tego celu metodologię analizy 
regionalnej i kontynuował przez cały okres kariery zawodowej. Wyniki tych badań opublikował w ponad 30 artykułach naukowych, mapach i dwóch książkach (praca habilitacyjna i tzw. monografia profesorska).

Wszystkie opublikowane prace zarówno te, które zawierają empiryczną weryfikację określonych tez, jak i te próbujące rozwinąć istniejące koncepcje lub sformułować nowe, przyczyniły się poważnie do rozwoju nurtu strukturalno-funkcjonalnego w polskiej geografii osadnictwa. Problemy podnoszone w tych pracach to:

a) tożsamość filozoficzna nurtu strukturalno-funkcjonalnego i sposób w jaki opisuje on w geografii miast człowieka oraz otaczającą go rzeczywistość,

b) znaczenie funkcji miejskich w procesach integrujących lub dezintegrujących sieć osadniczą na poziomie regionalnym,

c) ewolucja struktury funkcjonalnej i funkcji miast oraz czynników sprawczych wywołujących tę zmianę oraz jej skutki w przestrzeni miejskiej,

d) rozumienia $w$ geografii miast terminu funkcja i poszerzenie jego zakresu treści oraz związanie funkcji z konkretnym miejscem.

Całość rozwijanej w pracach A. Suliborskiego myśli odnosi się do sformułowania nowych diachronicznych ujęć funkcjonalnych i ich konotacji społecznych. Istotą jest odejście od ahistoryczności, przez włączenie w proces poznawczy wektora czasu, oraz rozszerzenie zakresu rozumienia pojęcia funkcja miasta o jej społeczną treść i interpretację. Wprowadzając do badań funkcjonalnych czynnik czasu A. Suliborski przedstawił metodologię badania procesu zmian funkcjonalnych. Wprowadzona koncepcja genetyczno-funkcjonalna opisuje dzieje funkcjonalne miasta jako pochodną tzw. czynników funkcjonalnych.

$\mathrm{Z}$ kolei interpretując miasto $\mathrm{w}$ kategoriach miejsca i terytorium człowieka, który jest twórcą, użytkownikiem i sprawcą wszystkich zmian, A. Suliborski sformułował koncepcję funkcji miejsca, definiując ją jako korelat treści materialno-informacyjnych oraz przypisywanych miejscu społecznych znaczeń i wartości. Opracowany program stanowi płaszczyznę integracji badań funkcjonalnych i morfologicznych oraz jest łącznikiem pomiędzy podejściem klasycznym w geografii miast (bliskim radykalnemu empiryzmowi) a humanistycznym. Rekonstrukcja badan funkcjonalnych, którą A. Suliborski przeprowadził w geografii społeczno-ekonomicznej, została przedstawiona w jego książce pt. Funkcjonalizm w polskiej geografi miast. Studia nad geneza i pojęciem funkcji (2010). Stanowi ona podsumowanie jego wieloletnich badań empirycznych i przemyśleń teoretycznych nad funkcjonalizmem w polskiej geografii miast oraz przedstawia pewne nowe sposoby jego interpretacji Jej autor wyraża przekonanie, że funkcjonalizm w geografii nie wyczerpał jeszcze swoich możliwości opisu i wyjaśniania zjawisk miejskich pod warunkiem nowej konceptualizacji pojęcia funkcji w geografii jako kategorii polimorficznej. Istotnym osiągnięciem poznawczym pracy jest rekonstrukcja znaczeń i zakresu treści kluczowego dla nurtu funkcjonalnego pojęcia 
funkcji prowadząca do jego klasyfikacji i osadzenia w kontekście różnych podejść teoretyczno-metodologicznych.

Ważnym aspektem działalności naukowej A. Suliborskiego, w zakresie problematyki miejskiej, są różne niepublikowane opracowania eksperckie na potrzeby miast. Były to studia z zakresu problematyki mieszkaniowej, oceny funkcjonowania gospodarek miast, strategie rozwoju miast i inne.

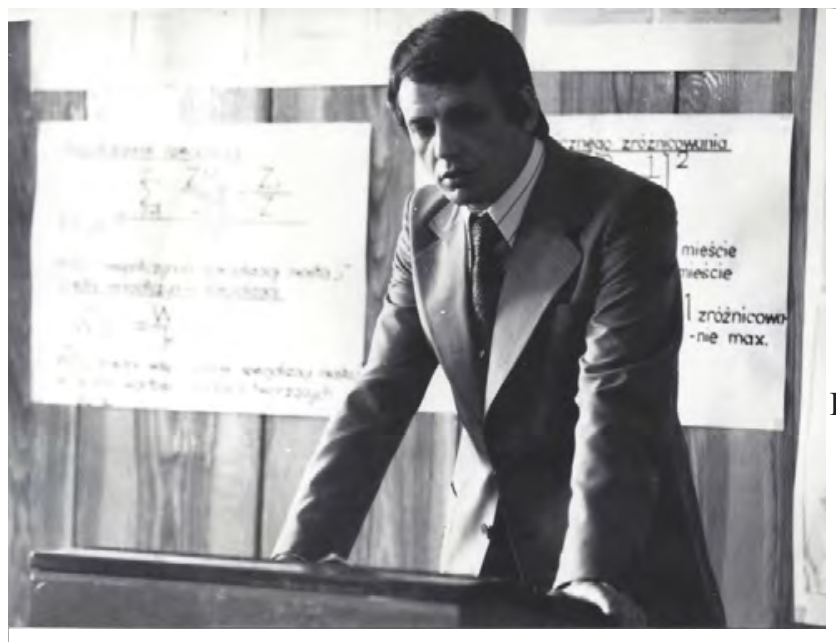

Fot. 1. Prof. Andrzej Suliborski podczas obrony pracy doktorskiej (1976 r.)

Źródło: materiały archiwalne Katedry Geografii Politycznej i Studiów Regionalnych UŁ

\section{Dorobek w zakresie geografii regionalnej}

W zakresie geografii regionalnej dorobek naukowy A. Suliborskiego liczy blisko 40 publikacji oraz kilkadziesiąt opracowań niepublikowanych wykonanych na rzecz gospodarki regionalnej. Badania te dotyczą studiów regionalnych o charakterze naukowo-utylitarnym prowadzonych w różnych regionach - głównie jednak w regionie łódzkim, a także edukacji i dydaktyki regionalnej, w ramach której opublikował kilka podręczników (6 książek) i artykułów.

Studia regionalne A. Suliborskiego, zwłaszcza te odnoszące się do regionu łódzkiego, wynikają z profilu naukowego Katedry i prowadzonej dla studentów specjalizacji, na której miał wykłady. Niewątpliwie, na zainteresowanie studiami regionalnymi miał wpływ odbyty staż specjalistyczny w Biurze Planowania Regionalnego Makroregionu Środkowo-Zachodniego w Poznaniu. Po powrocie z Poznania wraz z doc. dr Zdzisławem Batorowiczem rozpoczął badania nad powołanymi w 1975 roku w Polsce makroregionami. Posumowaniem tych studiów była książka z 1983 roku pt. Geografia ekonomiczna Polski. Makroregiony gospodarczo-planistyczne (która miała trzy zmienione wydania). Głównym założeniem pracy była identyfikacja struktury regionalnej Polski przez ustalenie geograficznej indywidualności regionów. Badania regionalne odnosiły się, z małymi wyjątkami 
związanymi z pracami na rzecz gospodarki (Śląsk Opolski), do obszaru regionu łódzkiego. Prace te dotyczyły regionu BOP (Bełchatowski Okręg Przemysłowy) oraz struktur przestrzenno-funkcjonalnych województw sieradzkiego i piotrkowskiego.

Odrodzenie się podmiotowości regionalnej oraz tocząca się dyskusja nad potrzebą zmiany podziału administracyjnego państwa stanowiły główne motywy podjęcia przez A. Suliborskiego studiów dotyczących podziałów administracyjnych na obszarze środkowej Polski. Miały one w dużej mierze charakter regionalnych studiów z geografii społeczno-politycznej. Początkowo dotyczyły one zagadnień ogólnych, takich jak: region i regionalizm jako kategorii geografii politycznej, uwarunkowania polityczne i społeczne koncepcji podziałów administracyjnych Polski, ideologiczne dylematy współpracy transgranicznej w jednoczącej się Europie. Później miały już charakter studiów empirycznych poświęconych preferencji administracyjnej i akceptacji reformy terytorialnej przez mieszkańców. Synteza tych badań znalazła się we współautorskiej książce poświęconej delimitacji potencjalnego obszaru województwa łódzkiego, nagrodzonej przez Prezydenta Miasta Łodzi.

Po reformie ustroju terytorialnego i powołaniu 16 województw A. Suliborski zajął się badaniem problemu funkcjonowania drugiego ogniwa (powiatów) administracji krajowej na obszarze aglomeracji łódzkiej. Wyniki tych badań opublikowane zostały we współautorskiej książce, która dostarczyła naukowych przesłanek do podejmowania decyzji o zmianach podziału administracyjnego na tym obszarze.

Badania nad elementami struktury regionalnej A. Suliborski przedstawił najpierw w postaci dwóch rozdziałów w monografii województwa łódzkiego, a następnie współredagując dwie książki poświęcone kształtowaniu się łódzkiego regionu społeczno-gospodarczego oraz procesom jego przestrzennej transformacji (razem z prof. Aleksandrą Jewtuchowicz). Opracowania te są ze sobą komplementarne, pierwsze - w części retrospektywnej, identyfikuje strukturę regionalną oraz główne procesy modelujące jej zmianę, drugie - wskazuje na relację pomiędzy transformacją regionu a procesami globalnymi i ukazuje, na przykładzie badanych przypadków, zróżnicowanie przestrzenne procesów zmiany regionu łódzkiego w płaszczyznach gospodarczej, społecznej i osadniczej. Książki te są ukoronowaniem długoletnich badań A. Suliborskiego nad przestrzenią regionalną województwa łódzkiego.

Bardzo ważną dziedziną studiów regionalnych były także opracowania, ekspertyzy, strategie, diagnozy (ponad 20), wykonane przez A. Suliborskiego na potrzeby samorządowych władz regionalnych różnego szczebla administracyjnego, a także opracowania naukowe wykonywane w ramach realizacji tematów tzw. centralnych lub Komitetu Badań Naukowych. 
Za największe osiągnięcie naukowe A. Suliborskiego w zakresie studiów regionalnych należy uznać dopracowanie metodologii analizy regionalnej, polegającej na odejściu od ujęcia monograficznego na rzecz badania najważniejszych problemów charakterystycznych dla regionu i ich wyjaśnianiu na podstawie celowo wybranych studiów przypadków.

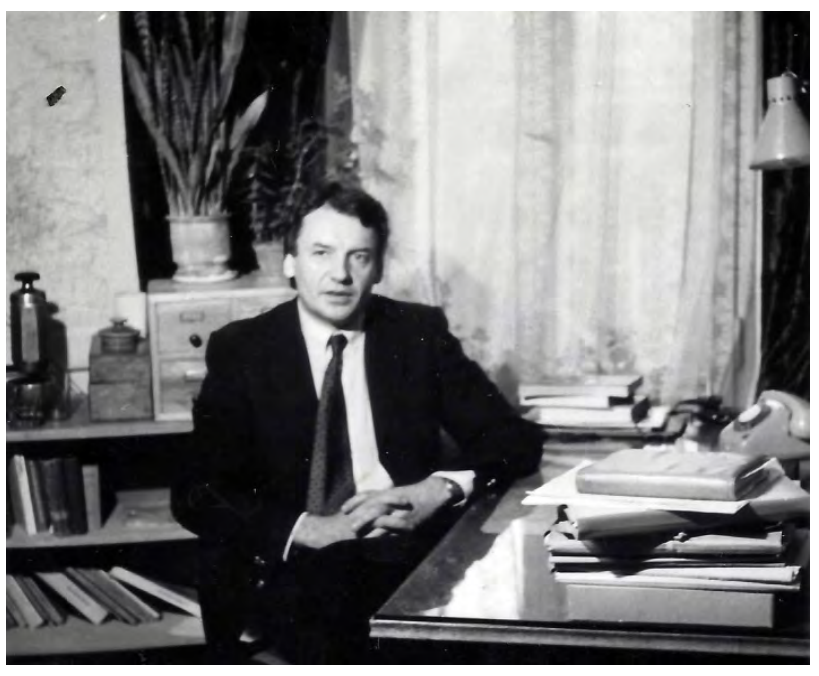

Fot. 2. Prof. Andrzej Suliborski w pracy (1987 r.)

Źródło: materiały archiwalne Katedry Geografii Politycznej i Studiów Regionalnych UŁ

Zainteresowanie edukacją i dydaktyką regionalną A. Suliborski zawdzięcza doc. dr. Zdzisławowi Batorowiczowi, wybitnemu dydaktykowi i specjaliście w zakresie geografii osadnictwa. Efektem tej współpracy było opracowanie nowoczesnego podręcznika do nauczania geografii Polski w liceum, którego pierwsze wydanie noszące tytuł Polska w Europie - podręcznik geografii dla szkoty średniej ukazało się w 1988 roku (z doc. dr. Zdzisławem Batorowiczem oraz ówczesnym geografem fizycznym dr. Jackiem Nalewajko). Podręcznik prezentował główne geograficzne cechy polskiej przestrzeni na tle innych krajów europejskich, a w swoich założeniach metodycznych ograniczał wiedzę faktograficzną na rzecz wyjaśniania i uczenia o zjawiskach, procesach i związkach pomiędzy człowiekiem a środowiskiem geograficznym. Książka doczekała się jedenastu wydań (ostatnie w roku 2000), co jak się wydaje, dobrze świadczy o jej walorach dydaktycznych. Uzupełnieniem podręcznika była, napisana w tym samym składzie autorskim i wydana w roku 1993 oraz wznowiona w 1995 roku książka, która stanowi pracę metodyczną wspomagającą nauczycieli, ale także rozszerzającą niektóre zagadnienia poruszane w podręczniku. Efektem zainteresowań edukacją regionalną A. Suliborskiego było opublikowane opracowanie zespołowe oryginalnego programu kształcenia regionalnego w zakresie dziedzictwa kulturowego Łodzi i Regionu Polski Środkowej dla różnych poziomów 
nauczania. Rozwinięciem idei zawartych w tym programie było wydanie dwóch książek - pierwszych podręczników do edukacji regionalnej, przeznaczonych dla uczniów liceum i gimnazjum.

\section{Zainteresowania ideowymi korzeniami i tożsamością geografii}

Zainteresowania podstawami teoretycznymi i metodologicznymi geografii towarzyszą A. Suliborskiemu od początku pracy naukowej, co wyrażał w wielu swoich artykułach, bez względu na ich problematykę przedmiotową. Stały się one jednak przedmiotem szczególnych zainteresowań już po uzyskaniu stopnia doktora habilitowanego. Refleksje, uogólnienia i syntezy odnoszą się przede wszystkim do geografii miast i studiów regionalnych, ale także do całej geografii, którą zawsze traktował jako jedną naukę zasadniczo odmienną, w swoich założeniach teoretyczno-metodologicznych, od innych.

Najważniejsze doświadczenia zdobył podczas pisania pracy habilitacyjnej, oraz później, książki poświęconej terminologii i pojęciom z geografii politycznej i geopolityki, we współpracy z prof. Marinem Baczwarowem. Obie prace wymagały przeprowadzenia szerokich studiów i głębokiego namysłu nad pojęciami odnoszącymi się do szeroko rozumianej problematyki społecznej. Szereg zawartych w książkach terminów i pojęć niejednokrotnie wymagało po raz pierwszy sprecyzowania i nadania im nowych znaczeń.

W zakresie geografii miast i osadnictwa zajmował się przede wszystkim funkcjonalizmem w geografii miast publikując $\mathrm{z}$ tego zakresu szereg artykułów teoretycznych, których uogólnienie zawarł w pracy habilitacyjnej, a później w książce syntetyzującej i rozwijającej nurt funkcjonalny przez nadanie mu nowych treści i znaczeń.

Przemyślenia teoretyczne w zakresie geografii regionalnej odnosiły się do jej fundamentalnego pojęcia jakim jest region, jego roli w syntezie geograficznej i edukacji oraz znaczenia geografii regionalnej dla naukowego sensu i jedności geografii.

Praca nad książką, przemyślenia teoretyczne w zakresie geografii miast oraz geografii regionalnej doprowadziły A. Suliborskiego do rozważań nad jednym z kluczowych problemów dla geografii, którym jest jej naukowa tożsamość. Geografia jest trudno porównywalna do innych nauk, zarówno na zasadach przedmiotowych, jak i metodologicznych, stąd pytanie o jej sens i specyfikę jest w pełni zasadne. Próbując znaleźć odpowiedź A. Suliborski odwołuje się do koncepcji regionalnej, która w jego przekonaniu jest najbliższa temu, czym $\mathrm{w}$ istocie jest geografia jako nauka. Uważa, że w syntezie wiedzy regionalnej tkwi tożsamość naukowa geografii.

Zainteresowania teoretyczne geografią A. Suliborskiego znalazły najpełniejszy wyraz w organizowanym od 2004 roku seminarium, razem z prof. Wiesławem Maikiem i z prof. Krystyną Rembowską, zatytułowanym Podstawowe idee 
$i$ koncepcje w geografii. Efektem tych spotkań i dyskusji jest 9 monografii naukowych pod wspólną redakcją organizatorów, w których znalazły się artykuły i wypowiedzi dyskusyjne wielu polskich geografów, a w przygotowaniu wydawniczym jest tom 10 zamykający cykl spotkań. Książki te są ważną wypowiedzią polskich geografów w sprawach istotnych dla rozwoju geograficznej myśli teoretycznej, a mianowicie: zaawansowania poziomu teoretycznego geografii, indywidualnego oglądu jej przestrzeni poznania, podstaw jedności, roli i znaczenia naszej dyscypliny wobec wyzwań przyszłości, podstawowych kategorii geograficznych, takich jak: region, krajobraz, przestrzeń, miejsce, terytorium, czas czy też postrzeganie człowieka w geografii.

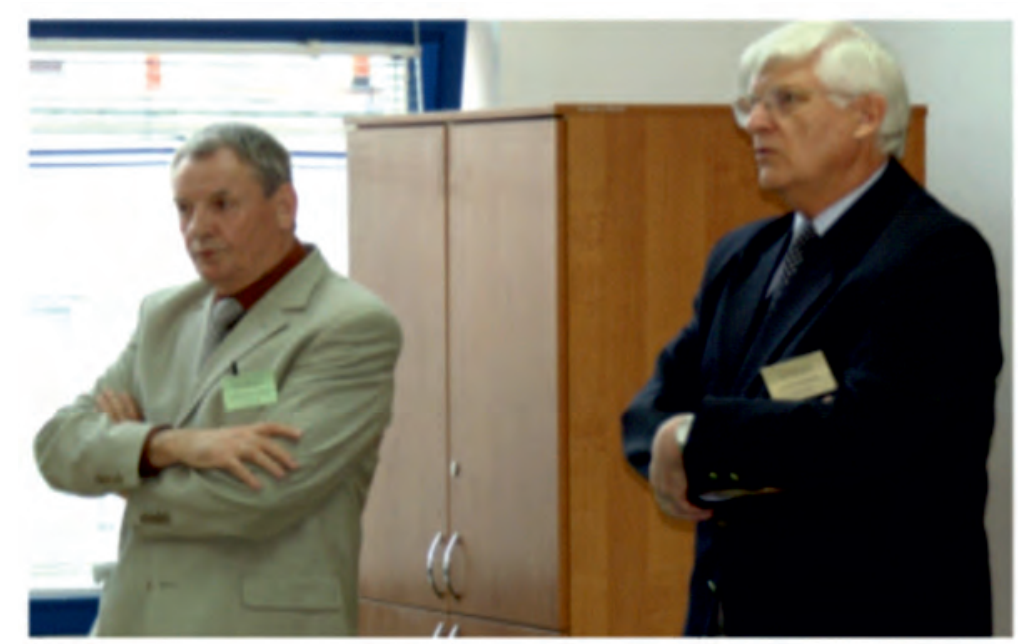

Fot. 3. Prof. Andrzej Suliborski i Prof. Marek Koter podczas otwarcia konferencji w Łodzi z cyklu „Podstawowe idee i koncepcje w geografii” (2007)

Źródło: materiały archiwalne Katedry Geografii Regionalnej i Społecznej

Zebrane w niniejszym tomie Folia Geographica Socio-Oeconomica (t. 27) prace stanowią pokłosie konferencji naukowej, która odbyła się w ramach Jubileuszu 70. lat życia i 47-lecia pracy naukowej i dydaktycznej prof. dr hab. Andrzeja Suliborskiego w dniu 17 czerwca 2016 roku na Wydziale Nauk Geograficznych Uniwersytetu Łódzkiego. Sesja Jubileuszowa i konferencja naukowa zgromadziły liczną rzeszę geografów oraz przedstawicieli pokrewnych dziedzin z różnych ośrodków, studentów, a także rodzinę i przyjaciół Profesora. Sesje i towarzyszące im spotkania były swoistą refleksją nad czasem, który wspólnie przeżywaliśmy i przeżywamy, a także zetknięciem z ideami naukowymi i dydaktycznymi towarzyszącymi życiu Jubilata. 
Sesję poświęconą dorobkowi naukowemu, dydaktycznemu oraz organizacyjnemu otworzył dr hab., prof. nadzw. UŁ Marcin Wójcik, który powitał przybyłych gości. Słowo wstępne wygłosił prof. dr hab. Antoni Różalski - Prezes Łódzkiego Towarzystwa Naukowego, Prorektor Uniwersytetu Łódzkiego ds. Nauki (od 2016 roku JM Rektor Uniwersytetu Łódzkiego). Gratulacjom ze strony władz Uniwersytetu Łódzkiego i Łódzkiego Towarzystwa Naukowego towarzyszyło przekazanie na ręce Jubilata opracowania wydanego przez Łódzkie Towarzystwo Naukowe z serii „Sylwetki Łódzkich Uczonych” pt. Profesor Andrzej Suliborski (2016). W imieniu władz i pracowników Wydziału Nauk Geograficznych Uniwersytetu Łódzkiego gratulacje złożył oraz słowo wstępne wygłosił Dziekan WNG UŁ prof. dr hab. Tadeusz Marszał.

Kolejną część Sesji Jubileuszowej wypełniły dwa wystąpienia odnoszące się do dokonań naukowo-dydaktycznych i organizacyjnych prof. Andrzeja Suliborskiego. W pierwszej kolejności przedstawiono zarys działalności Jubilata (zreferował prof. nadzw. UŁ, dr hab. Marcin Wójcik). Najważniejsze fakty z dorobku naukowego, dydaktycznego i organizacyjnego zostały wzbogacone o archiwalne fotografie i inne materiały dokumentujące aktywność Jubilata. Podarunkiem od zespołu Katedry Geografii Regionalnej i Społecznej UŁ dla Profesora był specjalnie przygotowany z tej okazji tom pt. Miasto - region - tożsamość geografii. Wybór prac Andrzeja Suliborskiego (Wydawnictwo UŁ, 2016). Wystąpienie prof. dr. hab. Wiesława Maika, oprócz gratulacji, zawierało refleksję nad twórczością naukową, widzianą z punktu widzenia długoletniej współpracy z Jubilatem. W części tej życzenia oraz gratulacje złożył oraz podzielił się wspomnieniami prof. dr hab. Marek Koter - wieloletni kierownik Katedry Geografii Politycznej i Studiów Regionalnych, w której Jubilat spędził dużą część swego naukowego życia. Prowadzący Sesję Jubileuszową odczytał wprowadzenie do tomu wydanego przez Łódzkie Towarzystwo Naukowe przygotowane przez śp. prof. dr. hab. Stanisława Liszewskiego zawierające osobiste wspomnienia i refleksje dotyczące długoletniej współpracy z Jubilatem.

Dużą część Sesji Jubileuszowej wypełniły życzenia i gratulacje ze strony przybyłych gości. W imieniu Komitetu Nauk Geograficznych PAN głos zabrał prof. dr hab. Andrzej Lisowski przekazując słowa podziękowania za wieloletnią pracę na rzecz środowiska naukowego geografów. Prof. dr hab. Andrzej Lisowski, jako Dziekan Wydziału Geografii i Studiów Regionalnych, wraz z przybyłymi współpracownikami (prof. dr hab. Mirosława Czerny, prof. dr hab. Andrzej Kowalczyk, dr hab. Bogumiła Lisocka-Jaegermann, dr hab. Izabella Łęcka), przekazał życzenia w imieniu własnym oraz całego środowiska naukowego WGiSR UW. Ze strony Instytutu Geografii Społeczno-Ekonomicznej i Gospodarki Przestrzennej Uniwersytetu Adama Mickiewicza podziękowania za długoletnią współpracę oraz gratulacje przekazali prof. dr hab. Tadeusz Stryjakiewicz, prof. dr hab. Tomasz Kaczmarek, prof. nadzw. dr hab. UAM Paweł Churski wraz ze współpra- 


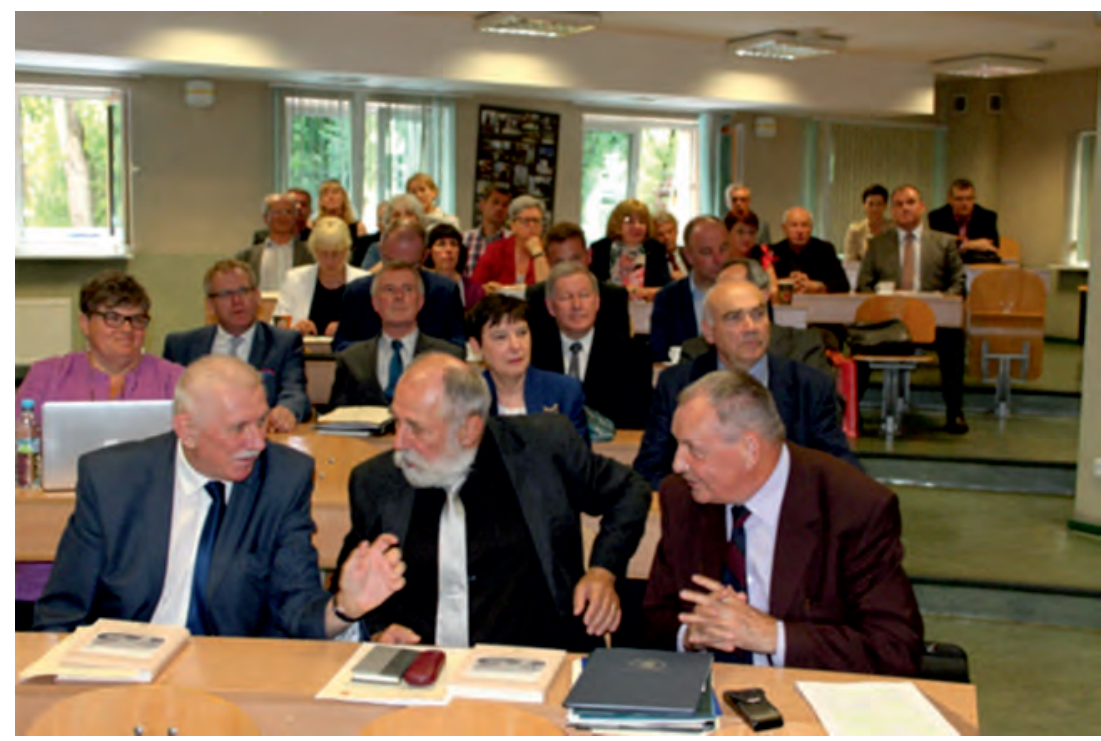

Fot. 4. Uczestnicy Sesji Jubileuszowej w dn. 17.06.2016 r.

W pierwszym rzędzie prof. Antoni Różalski, prof. Tadeusz Marszał, prof. Andrzej Suliborski

Źródło: materiały archiwalne Katedry Geografii Regionalnej i Społecznej

cownikami. Gratulacje i życzenia w imieniu własnym oraz ośrodków geograficznych złożyli również prof. dr hab. Jerzy Runge (Uniwersytet Śląski), dr Marika Pirveli (Uniwersytet Szczeciński), prof. nadzw. UP, dr hab. Danuta Piróg (Uniwersytet Pedagogiczny w Krakowie), dr Magdalena Szmytkowska (Uniwersytet Gdański), dr Wioletta Szymańska (Akademia Pomorska w Słupsku), prof. UMK, dr hab. Dariusz Sokołowski (Uniwersytet Mikołaja Kopernika), prof. nadzw. UP, dr hab. Peter Čuka, prof. UŁ, dr hab. Aleksandra Nowakowska (Katedra Gospodarki Regionalnej i Środowiska UŁ), mgr Maria Przybecka-Maik (WSG w Bydgoszczy). Słowa podziękowania wygłosili również: pierwszy Dziekan Wydziału Nauk Geograficznych UŁ prof. dr hab. Kazimierz Kłysik, prof. UŁ, dr hab. Bogdan Włodarczyk (w imieniu Instytutu Geografii Miast i Turyzmu UŁ), prof. UŁ, dr hab. Andrzej Rykała (w imieniu Instytutu Geografii Społeczno-Ekonomicznej i Organizacji Przestrzeni) oraz prof. dr hab. Joanna Wibig w imieniu pracowników Katedry Meteorologii i Klimatologii UŁ.

Spotkanie zgromadziło również liczną rzeszę współpracowników z Wydziału Nauk Geograficznych UŁ, kierowników i przedstawicieli jednostek naukowo-dydaktycznych. Gratulacje złożyli prof. dr hab. Krystyna Turkowska, prof. dr hab. Andrzej Matczak, prof. dr hab. Jolanta Jakóbczyk-Gryszkiewicz, prof. nadzw. UŁ, dr hab. Jerzy Dzieciuchowicz, prof. dr hab. Marek Sobczyński, prof. nadzw. UŁ, dr hab. Juliusz Twardy, prof. nadzw. UŁ, dr hab. Zbigniew Rdzany, dr Stanisław 


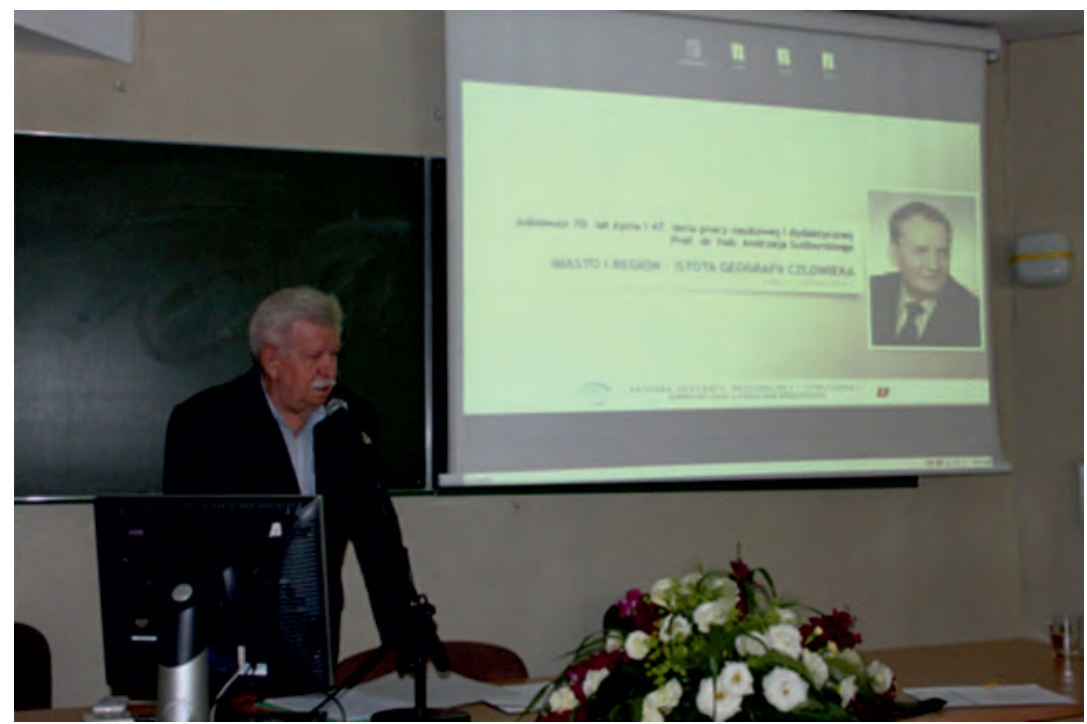

Fot. 5. Wystąpienie prof. Wiesława Maika podczas Sesji Jubileuszowej w dn. 17.06.2016 r.

Źródło: materiały archiwalne Katedry Geografii Regionalnej i Społecznej

Krysiak, prof. nadzw. UŁ, dr hab. Anita Wolaniuk, prof. nadzw. UŁ, dr hab. Jacek Kaczmarek, prof. nadzw. UŁ, dr hab. Elżbieta Szkurłat, prof. nadzw. UŁ, dr hab. Elżbieta Kobojek, prof. nadzw. UŁ, dr hab. Joanna Petera, prof. nadzw. UŁ, dr hab. Jacek Forysiak, prof. nazw. UŁ, dr hab. Marek Barwiński, prof. nadzw. UŁ, dr hab. Piotr Kittel, prof. nadzw. UŁ, dr hab. Stanisław Mordwa, prof. nadzw. UŁ, dr hab. Agnieszka Rochmińska, prof. nadzw. UŁ, dr hab. Mykoła Habrel, dr Anna Niżnik, dr Wojciech Retkiewicz, dr Tomasz Napierała, dr Ewa Szafrańska, dr Bartosz Bartosiewicz, mgr Iwona Gajda-Pijanowska, zespół Dziekanatu WNG UŁ reprezentowany przez Leonardę Spertusiak, Iwonę Andrzejewską oraz Kingę Napiórę oraz zespół Katedry Geografii Regionalnej i Społecznej - prof. nadzw. UŁ, dr hab. Marcin Wójcik, prof. nadzw. UŁ, dr hab. Anna Janiszewska, dr Danuta Walkiewicz, dr Paulina Tobiasz-Lis, dr Karolina Dmochowska-Dudek, dr Anita Kulawiak, mgr Anna Traczyk, mgr Justyna Tomczyk, mgr Paulina Kaszuba, mgr Małgorzata Dworak, mgr Krzysztof Burdyka, a także rodzina i przyjaciele, w tym brat Stanisław Suliborski i syn Filip Suliborski.

Listy gratulacyjne nadesłali: prof. $\mathrm{dr}$ hab. Grzegorz Węcławowicz i prof. dr hab. Marek Degórski w imieniu Rady Naukowej i Dyrekcji Instytutu Geografii i Przestrzennego Zagospodarowania PAN, prof. dr hab. Eugeniusz Rydz, prof. dr hab. Jerzy Parysek, dr hab. Dobiesław Jędrzejczyk, dr hab. Kry- 


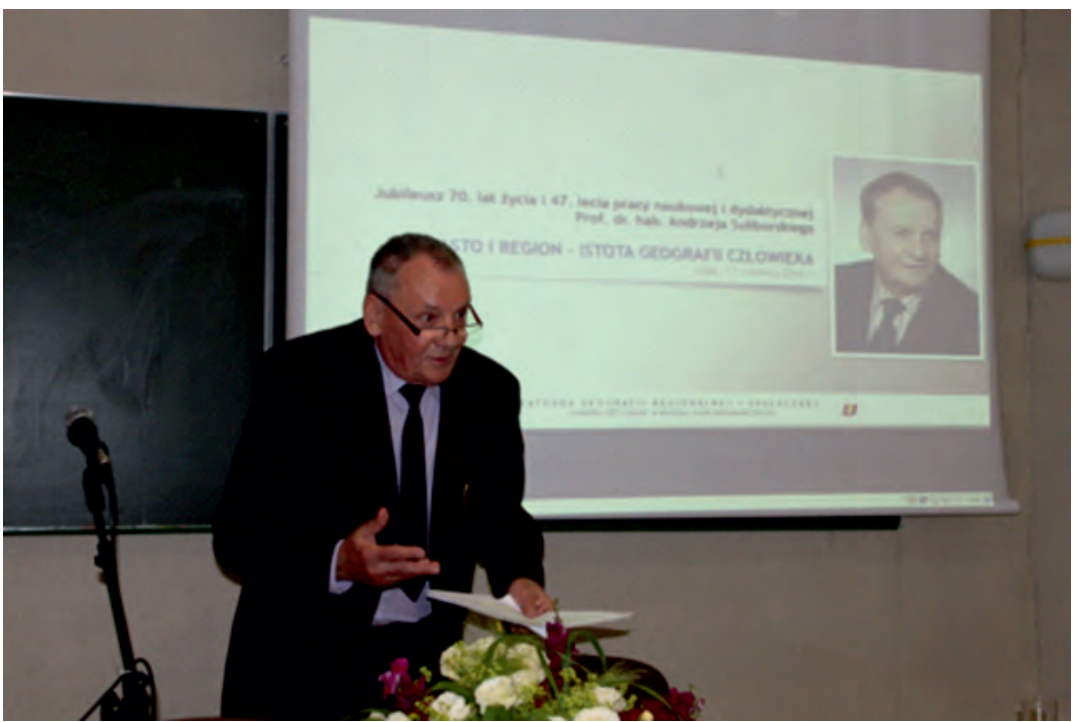

Fot. 6. Wystąpienie Jubilata prof. Andrzeja Suliborskiego w dn. 17.06.2016 r.

Źródło: materiały archiwalne Katedry Geografii Regionalnej i Społecznej

styna Rembowska, prof. AP, dr hab. Iwona Jażewicz, prof. dr hab. Jan Łoboda, prof. dr hab. Andrzej Kostrzewski, prof. dr hab. Marek Degórski w imieniu Komitetu Nauk Geograficznych, prof. dr hab. Teresa Czyż, prof. nadzw. UKW, dr. hab. Zbigniew Podgórski w imieniu Instytutu Geografii Uniwersytetu Kazimierza Wielkiego w Bydgoszczy, prof. dr hab. Adam Idziak w imieniu Rady Wydziały Nauk o Ziemi Uniwersytetu Śląskiego, prof. dr hab. Krzysztof Bąk w imieniu Instytutu Geografii Uniwersytetu Pedagogicznego, prof. AP, dr hab. Andrzej Icha w imieniu pracowników Instytutu Geografii i Studiów Regionalnych Akademii PomorskiejwStupsku,prof.drhab. Tadeusz Palmowskiw imieniu Katedry Geografii Rozwoju Regionalnego Uniwersytetu Gdańskiego, prof. dr hab. Mirosław Miętus w imieniu Instytutu Geografii Uniwersytetu Gdańskiego.

W części popołudniowej, w ramach sesji naukowych, część uczestników przedstawiła referaty nawiązujące do trzech głównych pól pracy naukowej Profesora Andrzeja Suliborskiego, tj. miasta i regionu w badaniach geograficznych oraz istoty i tożsamości geografii. Sesje podsumował prof. nazw. UŁ, dr hab. Marcin Wójcik. Podziękował on również wszystkim za uczestnictwo, życzenia oraz wzruszającą uroczystość, która była udziałem wszystkich, którzy pragnęli podzielić się refleksjami, wspomnieniami ze wspólnej drogi wśród geograficznych „pól” uprawianych przez prof. Andrzeja Suliborskiego. 


\section{Referaty zgloszone na sesje naukowe}

Antoni Jackowski (Uniwersytet Jagielloński) - „Ostatni przed wojną Zjazd Polskich Geografów w Krakowie. Instytut Geograficzny Uniwersytetu Jagiellońskiego, 28-29 maja 1939 roku";

Dobiesław Jędrzejczyk - „Człowiek i miejsce”;

Jan Loboda (Uniwersytet Wrocławski) - „Region jako podstawowa kategoria nauk geograficznych w kontekście funkcji odległości”;

Mirosława Czerny (Uniwersytet Warszawski) - „Badania geograficzne wobec wyzwań interdyscyplinarności studiów nad rozwojem";

Jerzy Runge (Uniwersytet Śląski) - „Przestrzeń społeczna miasta - dylematy geograficzno-metodologiczne";

Andrzej Matczak (Uniwersytet Łódzki) - „Turystyka w strukturze funkcjonalnej dużego miasta. Przykład Łodzi";

Jacek Kaczmarek (Uniwersytet Łódzki) - „Mądrość jako rozumienie świata”;

Eugeniusz Rydz, Iwona Jażewicz (Akademia Pomorska w Słupsku) - „Kurczenie się demograficzne miast województwa zachodniopomorskiego";

Tomasz Kaczmarek (Uniwersytet Adama Mickiewicza w Poznaniu) - „Suburbanizacja a zarządzanie i planowanie przestrzenne";

Marika Pirveli (Uniwersytet Szczeciński) - „Gruzińskie konotacje”;

Bogumila Lisocka-Jaegermann (Uniwersytet Warszawski) - „Regiony kulturowe w badaniach geografii człowieka";

Peter Čuka (Uniwersytet Pedagogiczny w Krakowie) - „Charakter współczesnego rozwoju turyzmu na Słowacji”;

Izabella Lęcka (Uniwersytet Warszawski) - „Region w zamorskich badaniach geograficznych - mikroprojekt w Iringa (Tanzania)";

Elżbieta Kobojek (Uniwersytet Łódzki) - „Tereny odzyskane, czyli użytkowanie wyrobisk poeksploatacyjnych w mieście";

Andrzej Rykala (Uniwersytet Łódzki) - „Geograficzno-polityczne i kulturowe uwarunkowania odradzania się oświaty żydowskiej w Polsce w pierwszych latach po drugiej wojnie światowej";

Emilia Bogacka (Uniwersytet Adama Mickiewicza w Poznaniu) - „Problematyka badawcza z zakresu poczucia bezpieczeństwa człowieka w przestrzeni miasta";

Barbara Konecka-Szydłowska, Robert Perdal (Uniwersytet Adama Mickiewicza w Poznaniu) - „Zróżnicowanie ludnościowo-osadnicze Polski w układzie województw";

Tomasz Hedorowicz (Uniwersytet Adama Mickiewicza w Poznaniu) - „Interwencja środowiskowa polityki spójności UE w Polsce - merytoryczne ukierunkowanie i regionalna koncentracja"; 
Tomasz Napierała (Uniwersytet Łódzki) - „Przestrzenne konteksty konkurencji”; Michal Dolata, Robert Perdal (Uniwersytet Adama Mickiewicza w Poznaniu) - „Regionalne ośrodki administracyjne okresu demokracji ludowej w Polsce i w Niemczech po 25 latach transformacji”.

Swoistym ,śladem”, który pozostawiliśmy dla potomnych, jest wybór prac prof. Andrzeja Suliborskiego pod redakcją Marcina Wójcika o tytule Miasto - region - tożsamość geografii (2016). Zebrane w tym tomie artykuły stanowią mały, choć reprezentatywny fragment rozległych zainteresowań naukowych Profesora. Publikację podzielono na trzy części, które odzwierciedlają główne pola prowadzonych badań - problematyka miasta (osadnictwa), region jako przedmiot badań geografii oraz ideowe korzenie i tożsamość geografii jako dyscypliny naukowej i edukacyjnej. Myślą przewodnią tego zbioru prac jest odwołanie się do przekonania Profesora, że geografia jest społecznie potrzebna i stanowi interesujący punkt widzenia miejsca człowieka $\mathrm{w}$ środowisku życia, a jej podstawy teoretyczno-metodologiczne pozwalają tworzyć pewne nadbudowy interpretacyjne oraz komunikować się z pokrewnymi dziedzinami. Wydanie tej pracy ma m.in. na celu wzmocnienie geograficznej tożsamości oraz pobudzenie do działania, zwłaszcza młodych geografów.

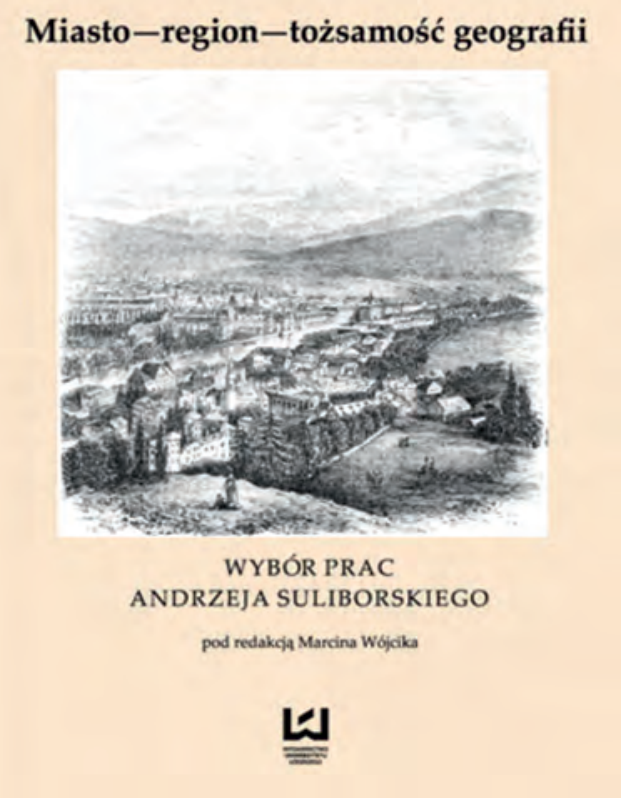

Ryc. 1. Pierwsza strona pracy poświęconej dorobkowi naukowemu Andrzeja Suliborskiego pt. Miasto - region - tożsamość geografii (red. Marcin Wójcik, 2016) 
Struktura pracy oparta na najważniejszych publikacjach (reprezentatywnych dla całego dorobku naukowego) w podziale na trzy pola zainteresowań badawczych

Pole zainteresowań

Środowisko mieszkaniowe i funkcje miasta jako przedmiot badań geografii osadnictwa
Publikacje

- Środowisko mieszkaniowe miasta jako przedmiot badań geografii osadnictwa

- Niektóre problemy badań funkcji miast w świetle podstawowych założeń koncepcji systemowej

- Genetyczno-systemowe ujęcie funkcji i struktury funkcjonalnej miasta

- Koncepcja funkcji miejsca

- Region and regionalism - a political-geographical approach

Region jako przedmiot $\quad-$ Region w nauczaniu geografii

badań geografii

- Geografia regionalna i jej znaczenie dla istoty geografii

- Metodyczne podstawy administracyjno-terytorialnej reorganizacji państwa w warunkach demokratycznych

- W poszukiwaniu geograficznej tożsamości Geografii osadnictwa i ludności

- Człowiek w geograficznych teoriach funkcjonalno-strukturalnych

- Jedność geografii a problem kształcenia akademickiego

- O znaczeniu syntezy naukowej w geografii

\section{Spis publikacji z lat 1970-2016}

\section{0}

Struktura przestrzenna osiedla mieszkaniowego Julianów w Łodzi, [w:] „Zeszyty Naukowe UŁ”, Seria II, 38, Łódź, s. 91-108.

\section{2}

Warunki mieszkaniowe centrum Kielc w ujęciu przestrzennym, [w:] „Zeszyty Naukowe UŁ”, Seria II, 49, Łódź, s. 37-65 (współautorzy: J. Dzieciuchowicz, B. Stolarczyk).

\section{6}

Struktura przestrzenna i gospodarka osady Trevelez (Wyniki badań terenowych $w$ górach

Sierra Nevada), [w:] „Acta Universitatis Lodziensis”, Seria II, 7, s. 147-179 (współautor: S. Liszewski).

Środowisko mieszkaniowe miasta jako przedmiot badań geografii osadnictwa, [w:] „Acta

Universitatis Lodziensis", Seria II, 7, s. 123-135. 
1977

Colonisation et economie en houte montagne: Treveles (Sierra Nevada, Espagne), [w:] „Mediterranee”, 1, s. 65-72 (współautor: S. Liszewski).

Główne cechy struktury przestrzennej województwa sieradzkiego, [w:] „Geografia w Szkole", 5, s. 195-200.

\section{8}

Zmiany funkcji miast województwa lódzkiego w latach 1960-1970 (streszczenie pracy doktorskiej), [w:] „Dokumentacja Geograficzna”, 6, Instytut Geografii Polskiej Akademii Nauk, s. 70-71.

\section{1}

Sieradz - studium struktury przestrzennej miasta, [w:] „Acta Universitatis Lodziensis. Folia Geographica", 1, Łódź, ss. 152 (współautor: L. Straszewicz).

Struktura i lokalizacja usług w Sieradzu, [w:] „Acta Universitatis Lodziensis. Folia Geographica", 1, Łódź, s. 91-100 (współautor: E. Dziegieć).

Zewnętrzne $i$ wewnętrzne strefy oddziaływania handlu detalicznego w Sieradzu, [w:] „Acta Universitatis Lodziensis. Folia Geographica”, 1, Łódź, s. 111-127 (współautor: E. Dziegieć).

\section{3}

Geografia ekonomiczna Polski. Makroregiony gospodarczo-planistyczne, Wydawnictwo Szkolne i Pedagogiczne, Warszawa, ss. 266 (współautor: Z. Batorowicz).

Niektóre problemy badań funkcji miast $w$ świetle podstawowych założeń koncepcji systemowej, [w:] „Acta Universitatis Lodziensis. Folia Geographica”, 2, Łódź, s. 3-16.

\section{4}

Funkcja turystyczna rejonu Zbiornika Otmuchowskiego, [w:] „Acta Universitatis Lodziensis. Folia Geographica", 3, Łódź, s. 99-117 (współautor: A. Matczak).

Region turystyczny i podstawy regionalizacji turystycznej kraju, [w:] Wolańska T. (red.), Rekreacja ruchowa i turystyka. Skrypt dla studentów AWF, Warszawa, s. 183-193.

\section{5}

Delimitacja strefy podmiejskiej Łodzi. Analiza pojęć i założeń metodologicznych, [w:] „Acta Universitatis Lodziensis. Folia Geographica”, 5, Łódź, s. 213-229.

Procesy urbanizacyjne $w$ strefie podmiejskiej na przykładzie gminy Dobroń, [w:] „Acta Universitatis Lodziensis. Folia Geographica”, 5, Łódź, s. 357-367 (współautor: W. Michalski).

Region miejski Nysy w świetle powiązań społeczno-gospodarczych, [w:] Materiały Ogólnopolskiego Zjazdu Polskiego Towarzystwa Geograficznego, Opole 5-8 września, Opole-Warszawa, s. 110-111 (współautor: W. Michalski).

Stan z okresu przedinwestycyjnego i wstęnej fazy pracy elektrowni, Liszewski S. (red.), Państwowe Wydawnictwo Naukowe, Warszawa-Łódź, s. 297-316.

Zmiana warunków mieszkaniowych na obszarze przyszłego Betchatowskiego Okręgu Przemystowego we wstęnej fazie industrializacji, [w:] Zmiany w środowisku przyszłego Bełchatowskiego Okręu Przemystowego. 
Zmiany $w$ środowisku $w$ rejonie BOP, [w:] Przeobrażenia ekonomiczno-społeczne w okręgu bełchatowskim i rybnickim, Zeszyty Badań Rejonów Uprzemysławianych, 78, Warszawa, s. 34-40 (współautor: S. Liszewski).

\section{6}

Le role de l'emigration daus le developpement demographique de la ville sur l'exemple de la population d'origine polonaise dans l'agglomeration de Saint-Etienne, [w:] Abstracts of papers, UGI, Barcelona VIII-IX, s. 70 (współautor: T. Marszał).

\section{7}

Les recherches sur les fonctions de la ville en geographie urbaine a la lumiere des courants structuralistes dans les sciences humaines, [w:] „Acta Universitatis Lodziensis. Folia Geographica", 10, Łódź, s. 107-118.

\section{8}

Geografia ekonomiczna Polski. Makroregiony gospodarczo-planistyczne, Wydawnictwo Szkolne i Pedagogiczne, Warszawa, wyd. II poszerzone, ss. 280 (współautor: Z. Batorowicz).

Podręcznik „Polska w Europie” - refleksja autorska, [w:] „Geografia w Szkole”, 4, s. 211-214 (współautor: J. Nalewajko).

Polska w Europie - podręcznik geografii dla szkoty średniej, Wydawnictwo Szkolne i Pedagogiczne, Warszawa, ss. 293 (współautorzy: Z. Batorowicz, J. Nalewajko), kolejne wydania: 1991, 1993, 1996, 1997, 1998, 2000.

Propozycja planu materiatu nauczania geografii „Polska w Europie”, [w:] „Geografia w Szkole", 2, s. 84-104 (współautor: Z. Batorowicz, J. Nalewajko).

\section{9}

Humenne - centre Tchecoslovaque de la production de fibres chimiques, [w:] „Problems in Textile Geography", 3, s. 101-109 (współautor: R. Istok).

Metodologiczne podstawy badań funkcji i struktury funkcjonalnej miast, [w:] „Geografia w Szkole", 5, s. 291-300.

Region miejski Nysy w świetle powiązań społeczno-gospodarczych, [w:] „Studia Społeczno-Ekonomiczne", 14, Opole, s. 47-61 (współautor: W. Michalski).

Warunki bytu ludności jako przedmiot zainteresowań geografii szkolnej, [w:] „Geografia w Szkole", 4, s. 257-258 (współautor: J. Nalewajko).

\section{1}

Istota i funkcja geografii a system edukacji, [w:] „Geografia w Szkole”, 5, s. 272-275.

Przemiany funkcji i struktury funkcjonalnej Łodzi, [w:] „Geografia w Szkole”, 1, s. 24-34.

\section{2}

Geneza procesów przemian funkcji i struktury funkcjonalnej Łodzi, [w:] Kronika Miasta Łodzi, s. 76-86.

\section{3}

Geografia ekonomiczna Polski. Ujęcie regionalne, Wydawnictwo Szkolne i Pedagogiczne, Warszawa, wyd. III zmienione, ss. 230 (współautor: Z. Batorowicz).

Polska w Europie. Geograficzne studia i zadania dla szkoły średniej, Wydawnictwo Szkolne i Pedagogiczne, Warszawa, ss. 176 (współautorzy: Z. Batorowicz, J. Nalewajko), kolejne wydanie 1995. 
Socio-economic spatial studies in the University of Łódź, [w:] Planning and Environment in the Łódź Region, 1/93, Kronika Miasta Łodzi, Zarząd Miasta Łodzi, Łódź, s. 77-92.

\section{4}

Genetyczno-systemowe ujęcie funkcji i struktury funkcjonalnej miasta, [w:] Zagadnienia Geografii Historycznej Osadnictwa w Polsce, Materiały Konferencyjne, Uniwersytet Mikołaja Kopernika, Uniwersytet Łódzki, Torun-Łódź, s. 39-45.

Koncepcja badań rozwoju układu regionalnego i lokalnego województwa piotrkowskiego, [w:] „Acta Universitatis Lodziensis. Folia Geographica”, 18, Łódź, s. 3-10, (współautor: M. Koter).

Ksztaltowanie się struktury funkcjonalno-przestrzennej oraz więzi regionalnych województwa piotrkowskiego, „Acta Universitatis Lodziensis. Folia Geographica”, 18, Łódź, ss. 130 (współautor: M. Koter).

Region and regionalism a political-geographical approach, [w:] Inner divisions region and regionalism, University of Łódź, Department of Political Geography and Regional Studies, Governmental Research Institute Silesian Institute in Opole, Łódź-Opole, s. 9-32 (współautor: M. Koter).

Struktura i rola funkcji przemysłowych miast $w$ integracji miejskiej sieci osadniczej województwa piotrkowskiego, [w:] „Acta Universitatis Lodziensis. Folia Geographica”, 18, Łódź, s. 55-76.

Struktura przestrzenno-funkcjonalna oraz więzi terytorialne $w$ regionie piotrkowskim - synteza problemu, [w:] „Acta Universitatis Lodziensis. Folia Geographica”, 18, Łódź, s. 115-122 (współautor: M. Koter).

Uwarunkowania polityczne i społeczne koncepcji podziałów terytorialnych Polski, [w:] Geopoliticke trendy $v$ streoeuropskych regionach a ich vplyv na teritorialne struktury. Zbornik z medzinarodneho seminara. Metodicke Centrum Banska Bystrica, Univerzita M. Bela Banska Bystrica, s. 32-40.

\section{5}

Gospodarka i warunki bytowe po II wojnie światowej, [w:] Szymczak J. (red.), Uniejów. Dzieje miasta, Towarzystwo Przyjaciół Uniejowa i Polskie Towarzystwo Historyczne, Łódź-Uniejów, s. 287-333.

Oświata i kultura. p. 1, Oświata i wychowanie, [w:] Szymczak J. (red.), Uniejów. Dzieje miasta, Towarzystwo Przyjaciół Uniejowa i Polskie Towarzystwo Historyczne, Łódź -Uniejów, s. 361-365 (współautor: T. Kunka).

Struktura własności i wielkości działek miejskich w Łasku, „Acta Universitatis Lodziensis. Folia Geographica", 20, s. 247-255.

Tomaszów Mazowiecki - rozwój struktury funkcjonalnej i przestrzennej miasta przemysłowego, [w:] Przewodnik Wycieczek XIII Ogólnopolskiego Zjazdu Polskiego Towarzystwa Geograficznego, Wydawnictwo Uniwersytetu Łódzkiego, Łódź, s. 133-142.

\section{6}

Delimitacja potencjalnego obszaru województwa łódzkiego. Studium Wiedzy o Regionie Łódzkim, Łódzkie Towarzystwo Naukowe, Łódź, ss. 83 i 25 map (współautorzy: M. Koter, S. Liszewski). 


\section{7}

Informator programowy kształcenia regionalnego $w$ zakresie dziedzictwa kulturowego Łodzi i Regionu Polski Środkowej dla nauczycieli przedszkoli, szkót podstawowych i średnich, [w:] Studium Wiedzy o Regionie Łódzkim, Łódzkie Towarzystwo Naukowe, Łódź, ss. 59 (współautorzy: M. Koter, M. Kulesza, S. Liszewski, J. Nalewajko, J. Salm, J. Siciński, T. Wieczorek).

\section{9}

Łódź i Region Polski Środkowej. Podręcznik wiedzy regionalnej dla liceów, Łódzkie Towarzystwo Naukowe, Łódź, ss. 369 (współautorzy: M. Koter, S. Liszewski), wyd. II uzupełnione 2001.

Metodyczne podstawy administracyjno-terytorialnej reorganizacji państwa $w$ warunkach demokratycznych, [w:] Suliborski A. (red.), Zasięg regionu łódzkiego w świetle badań społecznych preferencji przynależności administracyjnej i powiazań społeczno-gospodarczych (szczegółowe wyniki badań społeczności lokalnych w peryferycznej strefie potencjalnego województwa łódzkiego), „Acta Universitatis Lodziensis. Folia Geographica Socio-Oeconomica", 1, Wydawnictwo Uniwersytetu Łódzkiego, Łódź, s. 61-71.

Metodyczne i metodologiczne podstawy badań preferencji administracyjnej i poziomu akceptacji reformy terytorialnej oraz zwiazków przestrzennych mieszkańców wybranych gmin regionu tódzkiego, [w:] Suliborski A. (red.), Zasięg regionu tódzkiego w świetle badań społecznych preferencji przynależności administracyjnej i powiązań społeczno-gospodarczych (szczegółowe wyniki badań społeczności lokalnych w peryferycznej strefie potencjalnego województwa łódzkiego), „Acta Universitatis Lodziensis. Folia Geographica Socio-Oeconomica", 1, Wydawnictwo Uniwersytetu Łódzkiego, Łódź, s. 31-40.

Prace naukowo-badawcze poświęcone regionowi łódzkiemu wykonane w IGiOP Ut, [w:] Matczak A. (red.), Działalność naukowo-badawcza Instytutu Geografii Ekonomicznej i Organizacji Przestrzeni Uniwersytetu Lódzkiego do 1999 roku, Wydawnictwo Uniwersytetu Łódzkiego, Łódź, s. 37--46.

Społeczne preferencje przynależności administracyjnej mieszkańców południowo-zachodniej części Województwa Płockiego oraz ich powiązania funkcjonalne i migracyjne, [w:] Suliborski A. (red.), Zasięg regionu łódzkiego w świetle badań społecznych preferencji przynależności administracyjnej i powiązań społeczno-gospodarczych (szczegółowe wyniki badań społeczności lokalnych $w$ peryferycznej strefie potencjalnego województwa łódzkiego), „Acta Universitatis Lodziensis. Folia Geographica Socio-Oeconomica", Wydawnictwo Uniwersytetu Łódzkiego, Łódź, s. 73-85 (współautor: D. Walkiewicz).

Wstęp, [w:] Suliborski A. (red.), Zasięg regionu łódzkiego w świetle badań społecznych preferencji przynależności administracyjnej $i$ powiązań społeczno-gospodarczych (szczegółowe wyniki badań społeczności lokalnych w peryferycznej strefie potencjalnego województwa łódzkiego), ,Acta Universitatis Lodziensis. Folia Geographica Socio-Oeconomica", 1, Wydawnictwo Uniwersytetu Łódzkiego, Łódź, s. 3-5.

Zasięg regionu łódzkiego w świetle badań społecznych preferencji przynależności administracyjnej i powiąań społeczno-gospodarczych (szczegółowe wyniki badań społeczności lokalnych w peryferycznej strefie potencjalnego województwa łódzkiego), „Acta Universitatis Lodziensis. Folia Geographica Socio-Oeconomica", 1, Wydawnictwo Uniwersytetu Łódzkiego, Łódź, ss. 202. 


\section{0}

Funkcjonowanie powiatów w aglomeracji łódzkiej, powiat łódzki wschodni, pabianicki, zgierski, Katedra Geografii Politycznej i Studiów Regionalnych UŁ, Łódź, ss. 132 (współautorzy: E. Klima, A. Rykała, D. Walkiewicz).

Zmiany funkcji i struktury funkcjonalnej Łodzi oraz ich wpływ na formowanie się regionu Polski Środkowej (województwa łódzkiego), [w:] Cuka P. (red.), Rakusky Ustav Pre Vychodnu a Juhovychodnu Europu, „Acta Universitatis Matthiae Belli”, Faculta Prirodnych Vied., Banska Bystrica, s. 88-98.

Zmiany struktury funkcjonalnej miast polskich, które $w 1975$ roku uzyskały nowy status wojewódzki, [w:] Matlovic R. (red.), Urbanny Vyvoj Na Rozhrani Milenii, „Urbanne a Krajinne Studie”, 3, Filozoficka Fakulta Presovskej Universzity. Intitut Turizmu a Hoteloveho Manazmentu, Presov, s. 209-222 (współautor: D. Walkiewicz).

\section{1}

Funkcje i struktura funkcjonalna miast - studia empiryczno-teoretyczne. Komentarz do zbioru monotematycznych publikacji stanowiacych rozprawę habilitacyjna, Wydawnictwo Uniwersytetu Łódzkiego, Łódź, ss. 72.

Gospodarka rolna, [w:] Liszewski S. (red.), Funkcja regionalna Łodzi i jej rola w ksztattowaniu województwa. Zarys monografii województwa łódzkiego, Łódzkie Towarzystwo Naukowe, Łódź, s. 278-304.

Lasy, [w:] Liszewski S. (red.), Funkcja regionalna Łodzi i jej rola w ksztattowaniu województwa. Zarys monografii województwa łódzkiego, Łódzkie Towarzystwo Naukowe, Łódź, s. 304-310.

Problemy i kierunki rozwoju miejskiej sieci osadniczej województwa łódzkiego, [w:] Jewtuchowicz J. (red.), Strategiczne problemy rozwoju regionów w procesie integracji europejskiej, Zakład Ekonomiki Regionalnej i Ochrony Środowiska UŁ, Łódź, s. 106-115.

\section{2}

Funkcje Łodzi na tle miast europejskich. Mapa nr 4, [w:] Atlas Miasta Łodzi, Plansza XLVIII pt. Łódź w systemie powiązań międzynarodowych, Urząd Miasta Lodzi, Łódzkie Towarzystwo Naukowe, Łódź (współautor: D. Walkiewicz).

Funkcje Łodzi w regionalnej i krajowej sieci osadniczej. Mapa nr 6, [w:] Atlas Miasta Łodzi, Plansza XLIX pt. Oddziaływanie Łodzi na przestrzeń społeczno-gospodarcza kraju i regionu, Urząd Miasta Łodzi, Łódzkie Towarzystwo Naukowe, Łódź (współautor: D. Walkiewicz).

Funkcjonalna przemiana i integracja systemu miast $w$ regionie tódzkim, [w:] Jewtuchowicz J., Suliborski A. (red.), Struktury i procesy kształtujące łódzki region społeczno-gospodarczy, Zakład Ekonomiki Regionalnej i Ochrony Środowiska UŁ, Łódź, s. $168-211$.

Integracja społeczno-ekonomiczna i główne czynniki zwiększające wewnętrzna spójność regionu łódzkiego, [w:] Jewtuchowicz J., Suliborski A. (red.), Struktury i procesy kształtujące łódzki region społeczno-gospodarczy, Zakład Ekonomiki Regionalnej i Ochrony Środowiska UŁ, Łódź, s. 351-361 (współautor: A. Jewtuchowicz).

Kompendium wiedzy o geografii politycznej i geopolityce. Terminologia, Państwowe Wydawnictwo Naukowe, Warszawa-Lódź, ss. 189 (współautor: M. Baczwarow). 
Łódź $i$ województwo. Podręcznik wiedzy o regionie dla gimnazjum, Łódzkie Towarzystwo Naukowe, Łódź, ss. 292 (współautorzy: M. Koter, S. Liszewski, T. Wieczorek).

Łódź w systemie powiązań międzynarodowych, (plansza XLVIII), [w:] Liszewski S. (red.), Atlas Miasta Łodzi, Urząd Miasta Łodzi, Łódzkie Towarzystwo Naukowe, Łódź.

Międzynarodowa wspótpraca łódzkich uczelni. Mapa nr 2, [w:] Atlas Miasta Łodzi, Plansza XLVIII pt. Łódź w systemie powiązań międzynarodowych, Urząd Miasta Łodzi, Łódzkie Towarzystwo Naukowe, Łódź (współautor: E. Klima).

Oddziaływanie Łodzi na przestrzeń społeczno-gospodarcza kraju i regionu, (plansza XLIX), [w:] Liszewski S. (red.), Atlas Miasta Łodzi, Urząd Miasta Łodzi, Łódzkie Towarzystwo Naukowe, Łódź.

Położenie Łodzi na tle struktur przyrodniczych Łodzi i regionu, (plansza I), [w:] Liszewski S. (red.), Atlas Miasta Łodzi, Urząd Miasta Łodzi, Łódzkie Towarzystwo Naukowe, Łódź.

Położenie Łodzi na tle systemów polityczno-administracyjnych, transportowych i osadniczych, (plansza II), [w:] Liszewski S. (red.), Atlas Miasta Łodzi, Urząd Miasta Łodzi, Łódzkie Towarzystwo Naukowe, Łódź.

Struktury i procesy kształtujące łódzki region społeczno-gospodarczy, Zakład Ekonomiki Regionalnej i Ochrony Środowiska UŁ, Łódź, ss. 361 (współautor: J. Jewtuchowicz).

Zasięg oddziaływania Łodzi w ocenie społeczności lokalnych peryferyjnej strefy regionu łódzkiego. Mapa nr 3, [w:] Atlas Miasta Łodzi, Plansza XLIX pt. Oddziaływanie Łodzi na przestrzeń społeczno-gospodarcza kraju i regionu, Urząd Miasta Łodzi, Łódzkie Towarzystwo Naukowe, Łódź (współautor: D. Walkiewicz).

\section{3}

Koncepcja funkcji miejsca $w$ badaniu zróżnicowania społeczno-gospodarczego regionu miejskiego, [w:] Sagan I., Czepczyński M. (red.), Wymiar i współczesne interpretacje regionu, UG, Katedra Geografii Ekonomicznej, Gdańsk-Poznań, s. 217-225.

Region w syntezie i edukacji geograficznej, [w:] Orłowska E., Klementowski J. (red.), Kulturowy aspekt badań geograficznych. Studia teoretyczne i regionalne, Oddział Wrocławski Polskiego Towarzystwa Geograficznego, Instytut Geografii i Rozwoju Regionalnego Uniwersytetu Wrocławskiego, Wrocław, s. 51-63.

Region w teorii i badaniach naukowych, [w:] „Przegląd Edukacyjny”, 2(39), Wojewódzki Ośrodek Doskonalenia Nauczycieli w Łodzi, Łódź, s. 2-12.

\section{4}

Badania funkcjonalne $w$ polskiej geografii miast - refleksja metodologiczna (Ewolucja poglądów na funkcję i teorię bazy ekonomicznej miast), [w:] Ref lexie geografických výskumov v strednej Europę s dôrazom na ich využitie v praxi, Univerzita Mateja Bela v Banskej Bystrici, Fakulta prírodných vied, Katedra geografie, Geografické študie, 12, Banska Bystrica, s. 37-45.

Wnioski końcowe, [w:] Jackowski A. (red.), I Forum Geografów. Geografia u progu XXI wie$k u$, Uniwersytet Jagielloński, Kraków, s. 101-105.

\section{5}

Geografia jako nauka o przestrzeni, środowisku i krajobrazie. Podstawowe idee i koncepcje w geografii, (red. naukowa), t. 1, Łódzkie Towarzystwo Naukowe, Łódź, ss. 223 (współautor: M. Maik, K. Rembowska). 
Głos w dyskusji, [w:] Maik W., Rembowska K., Suliborski A. (red.), Podstawowe idee $i$ koncepcje w geografi, t. 1, Geografia jako nauka o przestrzeni, środowisku i krajobrazie, Łódzkie Towarzystwo Geograficzne, Łódź, s. 212-214.

Ksztatcenie geografów na poziomie akademickim w świetle aktualnej dyskusji o jedności geografii, [w:] Jania J., Jankowski A.T. (red.), Wpływ rozwoju nauk geograficznych na proces kształcenia społeczeństwa oraz promocję wiedzy geograficznej w Polsce, Komitet Nauk Geograficznych Polskiej Akademii Nauk, Uniwersytet Śląski, Sosnowiec, s. 9-20 (współautor: S. Liszewski).

Nekropolie jako miejsce w przestrzeni społeczno-kulturowej Łodzi, [w:] Domański B., Skiba S. (red.), Geografia i sacrum, t. 2, Instytut Geografii i Gospodarki Przestrzennej, Uniwersytet Jagielloński, Kraków, s. 441-453.

W poszukiwaniu geograficznej tożsamości geografii osadnictwa i ludności, [w:] Liszewski S., Maik W. (red.), Rola i miejsce geografii osadnictwa i ludności w systemie nauk geograficznych, Studia i materiały Instytutu Geografii i Gospodarki Przestrzennej Wyższej Szkoły Gospodarki w Bydgoszczy, Bydgoszcz, s. 106-113.

\section{6}

Człowiek $w$ badaniach geograficznych. Podstawowe idee $i$ koncepcje $w$ geografii, t. 2, Bydgoszcz, ss. 272 (współautor: W. Maik, K. Rembowska).

Człowiek $w$ geograficznych teoriach funkcjonalno-strukturalnych, [w:] Maik W., Rembowska K., Suliborski A. (red.), Człowiek w badaniach geograficznych. Podstawowe idee i koncepcje w geografii, t. 2, Bydgoszcz, s. 59-76.

Człowiek w przestrzeni, [w:] Maik W., Rembowska K., Suliborski A. (red.), Podstawowe idee i koncepcje w geografi, t. 2, Człowiek w badaniach geograficznych, Bydgoszcz, s. 259-261.

Geografia regionalna i jej znaczenie dla istoty geografii, [w:] Kostrzewski A. (red.), Geografia regionalna jako przedmiot badań i nauczania, Bogucki Wydawnictwo Naukowe, Poznań, s. 15-27.

Jedność geografii a problem ksztatcenia akademickiego, [w:] „Czasopismo Geograficzne", 77 (1-2), s. 3-22 (współautor: S. Liszewski).

Koncepcje człowieka $w$ geografi, człowiek a teorie i orientacje geograficzne, [w:] Maik W., Rembowska K., Suliborski A. (red.), Podstawowe idee i koncepcje w geografii, t. 2, Człowiek w badaniach geograficznych, Bydgoszcz, s. 237-239.

Nowy paradygmat rozwoju, [w:] Jewtuchowicz J., Suliborski A. (red.), Zróżnicowanie przestrzenne procesów transformacji społeczno-gospodarczej $w$ regionie łódzkim, Wydawnictwo Uniwersytetu Łódzkiego, Łódź, s. 343-358 (współautor: A. Jewtuchowicz).

Przedsiębiorca jako uczestnik i twórca procesów transformacji. Przykład Łodzi, [w:] Jewtuchowicz J., Suliborski A. (red.), Zróżnicowanie przestrzenne procesów transformacji społeczno-gospodarczej w regionie tódzkim, Wydawnictwo Uniwersytetu Łódzkiego, Łódź, s. 159-181 (współautor: A. Kulawiak).

The importance of regional geography for the unity of geography, [w:] „Geograficka Revue”, 2(2), Uniwersytet Mateja Bella, Bańska Bystrzyca, Słowacja, s. 40-48.

The importance of regional geography for the unity of geography, [w:] XIV Kongres SGS, Zbornik Abstraktow, Geografia v meniacom sa svete, Banska Bystrica, s. 8-9. 
Wstęp, [w:] Jewtuchowicz J., Suliborski A. (red.), Zróżnicowanie przestrzenne procesów transformacji społeczno-gospodarczej w regionie łódzkim, Wydawnictwo Uniwersytetu Łódzkiego, Łódź, s. 7-11 (współautor: A. Jewtuchowicz).

Zróżnicowanie przestrzenne procesów transformacji spoleczno-gospodarczej $w$ regionie łódzkim, Wydawnictwo Uniwersytetu Łódzkiego, Łódź, ss. 358 (współautor: A. Jewtuchowicz).

\section{7}

Geografia a przemiany współczesnego świata. Podstawowe idee i koncepcje w geografi, t. 3, Wydawnictwo Uczelniane Wyższej Szkoły Gospodarki w Bydgoszczy, Bydgoszcz, ss. 316 (współautorzy: W. Maik, K. Rembowska).

\section{8}

Doc. Dr Zdzisław Batorowicz - mój nauczyciel, profesor, kolega i przyjaciel, [w:] Sylwetki Łódzkich Uczonych, z. 88, Łódzkie Towarzystwo Naukowe, Łódź.

Funkcje miast, [w:] Liszewski S. (red.), Geografia urbanistyczna, Wydawnictwo Uniwersytetu Łódzkiego, Łódź, s. 235-282.

O znaczeniu syntezy naukowej w geografii, [w:] Liszewski S., Łoboda J., Maik W. (red.), Stan i perspektywy rozwoju geografii w Polsce, Komitet Nauk Geograficznych Polskiej Akademii Nauk, Wydawnictwo Wyższej Szkoły Gospodarki w Bydgoszczy, Bydgoszcz, s. 79-90.

Terytorium, region, miejsce - czas i przestrzeń w geografii. Podstawowe idee i koncepcje w geografii, t. 4, Wydawnictwo Uczelniane Wyższej Szkoły Gospodarki w Bydgoszczy, Bydgoszcz, ss. 230 (współautorzy: K. Rembowska, W. Maik).

\section{9}

Dostęność komunikacyjna Łodzi (plansza L), [w:] Liszewski S. (red.), Atlas Miasta Łodzi, Urząd Miast Łodzi, Łódzkie Towarzystwo Naukowe, Łódź (współautorzy: D. Walkiewicz, M. Wójcik).

Funkcje aglomeracji łódzkiej w systemie osadniczym kraju i regionu, [w:] Maik W. (red.), Aglomeracje miejskie w Polsce na przełomie XX $i$ XXI wieku. Problemy rozwoju, przekształceń strukturalnych i funkcjonowania, Wydawnictwo Wyższej Szkoły Gospodarki w Bydgoszczy, Bydgoszcz, s. (współautorzy: D. Walkiewicz, M. Wójcik).

Gospodarka Łodzi na przełomie XX i XXI wieku, [w:] Liszewski S. (red.), Łódź. Monografia miasta, Łódzkie Towarzystwo Naukowe, Łódź, s. 400-409 (współautor: A. Jewtuchowicz).

Kształtowanie się funkcji gospodarczych Łodzi do 1918 roku, [w:] Liszewski S. (red.), Łódź. Monografia miasta, Łódzkie Towarzystwo Naukowe, Łódź, s. 125-149 (współautor: A. Jewtuchowicz).

Struktura gospodarcza Łodzi w latach 1918-1989, [w:] Liszewski S. (red.), Łódź. Monografia miasta, Łódzkie Towarzystwo Naukowe, Łódź, s. 297-322 (współautor: A. Jewtuchowicz).

Współczesne zróżnicowanie społeczno-gospodarcze województwa łódzkiego, [w:] Badziak K., Łapa M. (red.), Województwo Łódzkie 1919-2009, Studia i Materiały, Wydawnictwo Polskiego Towarzystwa Historycznego, Łódź (współautor: D. Walkiewicz). 
Życie kulturalne Łodzi na przełomie XX i XXI wieku, [w:] Liszewski S. (red.), Łódź. Monografia miasta, Łódzkie Towarzystwo Naukowe, Łódź, s. 410-419 (współautor: A. Jewtuchowicz).

Życie społeczno-kulturalne Łodzi do 1918 roku, [w:] Liszewski S. (red.), Łódź. Monografia miasta, Łódzkie Towarzystwo Naukowe, Łódź, s. 150-159, (współautor: A. Jewtuchowicz).

Życie spoleczne i kulturalne Łodzi w latach 1918-1989, [w:] Liszewski S. (red.), Łódź. Monografia miasta, Łódzkie Towarzystwo Naukowe, Łódź, s. 322-342 (współautor: A. Jewtuchowicz).

\section{0}

Funkcja i struktura funkcjonalna Lódzkiego obszaru metropolitalnego, [w:] Jewtuchowicz A., Wójcik M. (red.), Łódzka metropolia. Problemy integracji gospodarczej, Łódź, s. 21-39 (współautor: D. Walkiewicz).

Funkcjonalizm w polskiej geografi miast, studia nad geneza i pojęciem funkcji, Wydawnictwo Uniwersytetu Łódzkiego, Łódź, ss. 181.

Łódzka metropolia. Problemy integracji społecznej i przestrzennej, Łódź, ss. 195 (współautor: Z. Przygocki).

Przemiany przestrzenne i funkcjonalne Łodzi po transformacji społeczno-gospodarczej, [w:] „Queastiones Geographicae”, Seria B, 28 B/2, Wydawnictwo Uniwersytetu im. Adama Mickiewicza, Poznań (współautorzy: M. Wójcik, A. Kulawiak).

The demographic and social differentiation of the large cities in Poland, [w:] Habrel M., Marszał T. (red.), Economic and social functions of Polish and Ukrainian big cities at the beginning of the $21^{\text {st }}$ century, Wydawnictwo Uniwersytetu Łódzkiego, Łódź, (współautor: M. Wójcik).

\section{1}

Geografia regionalna - scalenie i synteza wiedzy geograficznej. Podstawowe idee i koncepcje w geografii, t. 6, Wydawnictwo Uniwersytetu Łódzkiego, Łódź, ss. 218 (współautorzy: W. Maik, K. Rembowska).

Przemiana funkcji miejsca $w$ historycznej dzielnicy przemysłowej Łodzi - Posiadłach wodno-fabrycznych, [w:] Marciniak K., Sikora K., Sokołowski D. (red.), Koncepcje i problemy badawcze geografii, Wydawnictwo Wyższej Szkoły Gospodarki w Bydgoszczy, Bydgoszcz, s. 161-183.

Przemiany funkcjonalne Łodzi na przełomie wieków. Uwarunkowania systemowe, [w:] Kaczmarek S. (red.), Miasto. Księga jubileuszowa $w$ 70. rocznice urodzin Profesora Stanisława Liszewskiego, Wydawnictwo Uniwersytetu Łódzkiego, Łódź, s. 227-241, (współautorzy: M. Wójcik, A. Kulawiak).

Rola i miejsce edukacji geograficznej w społeczeństwie, [w:] Kostrzewski A., Maik W., Brudnicki R. (red.), Geografia wobec problemów współczesności. Funkcje poznawcze i praktyczne geografii, Komitet Nauk Geograficznych Polskiej Akademii Nauk, Wyższa Szkoła Gospodarki w Bydgoszczy, Bydgoszcz (współautor: M. Wójcik).

Ujęcia i problemy badawcze we współczesnej geografii. Podstawowe idee $i$ koncepcje w geografii, t. 5, Wydawnictwo Wyższej Szkoły Gospodarki w Bydgoszczy, Bydgoszcz, ss. 158 (współautorzy: W. Maik, K. Rembowska). 


\section{2}

Funkcje miast, [w:] Liszewski S. (red.), Geografia urbanistyczna, Państwowe Wydawnictwo Naukowe, Warszawa, s. 255-302.

Zwiazki geografii z innymi naukami. Podstawowe idee $i$ koncepcje w geografi, t. 7, Wydawnictwo Wyższej Szkoły Gospodarki w Bydgoszczy, Bydgoszcz, ss. 328 (współautorzy: W. Maik, K. Rembowska).

\section{3}

Geografia w ujęciu humanistycznym. Wybór prac Krystyny Rembowskiej, Wydawnictwo Uniwersytetu Łódzkiego, Łódź. ss. 284.

\section{4}

Dorobek polskiej geografii po konferencji w Rydzynie. Podstawowe idee $i$ koncepcje w geografii, t. 8, Wydawnictwo Uniwersytetu Łódzkiego, Łódź. ss. 242 (współautorzy: W. Maik, K. Rembowska).

Dysproporcje społeczne i gospodarcze w przestrzeni Łodzi. Czynniki, mechanizmy, skutki, Wydawnictwo Uniwersytetu Łódzkiego, Łódź. ss. 327 (współautor: M. Wójcik).

Dysproporcje w zagospodarowaniu przestrzeni miejskiej Łodzi - uwarunkowania genetyczno-funkcjonalne, [w:] Suliborski A., Wójcik M. (red.), Dysproporcje społeczne i gospodarcze w przestrzeni Łodzi. Czynniki, mechanizmy, skutki, Wydawnictwo Uniwersytetu Łódzkiego, Łódź, s. 77-105 (współautor: K. Dmochowska-Dudek).

Geografia społeczna w Polsce-geneza, koncepcje i zróżnicowanie problemowe ze szczególnym uwzględnieniem studiów geograficzno-miejskich w ośrodku łódzkim, [w:] Suliborski A., Wójcik M. (red.), Dysproporcje społeczne i gospodarcze w przestrzeni Łodzi. Czynniki, mechanizmy, skutki, Wydawnictwo Uniwersytetu Łódzkiego, Łódź, s. $16-48$.

Rady osiedlowe jako czynnik zmieniajacy dysproporcje $w$ przestrzeni miasta na przykładzie Łodzi, [w:] Suliborski A., Wójcik M. (red.), Dysproporcje społeczne i gospodarcze w przestrzeni Łodzi. Czynniki, mechanizmy, skutki, Wydawnictwo Uniwersytetu Łódzkiego, Łódź, s. 127-170.

The origin and development of social geography in Poland with special emphasis on the centre of geographical studies in Lódź, [w:] Marszał T. (red.), Society and space in contemporary Poland in Łódź University Geographical Research, Łódź University Press, s. 45-82 (współautor: M. Wójcik).

Wstęp, [w:] Suliborski A., Wójcik M. (red.), Dysproporcje spoteczne i gospodarcze w przestrzeni Łodzi. Czynniki, mechanizmy, skutki, Wydawnictwo Uniwersytetu Łódzkiego, Łódź, s. 7-15.

Zakończenie, [w:] Suliborski A., Wójcik M. (red.), Dysproporcje społeczne i gospodarcze w przestrzeni Łodzi. Czynniki, mechanizmy, skutki, Wydawnictwo Uniwersytetu Łódzkiego, Łódź, s. 321-327.

\section{5}

Wykorzystanie koncepcji ,funkcji miejsca” w badaniach wielofunkcyjnych obszarów wiejskich (przykład gminy miejsko-wiejskiej Rzgów w powiecie wschodnio-łódzkim, [w:] Biczkowski M., Kozłowski L. (red.), Wiejskie obszary funkcjonalne, „Studia Obszarów Wiejskich", 37, Komisja Obszarów Wiejskich, Instytut Geografii i Przestrzennego Zagospodarowania Polskiej Akademii Nauk, s. 71-90. 
2016

Nowe $i$ stare perspektywy $i$ ujęcia w geografii na przełomie XX i XXI wieku. Podstawowe idee i koncepcje w geografii, t. 10, Wydawnictwo Uniwersytetu Łódzkiego, Łódź, (współautor: W. Maik, M. Wójcik).

Stan, perspektywy i strategia rozwoju geografii spoteczno-ekonomicznej $w$ najbliższych 15 latach (do 2030 r.). Dyskusja międzypokoleniowa, Wydawnictwo Uniwersytetu Łódzkiego, Łódź.

Dr hab. Marcin Wójcik, prof. UŁ Katedra Geografii Regionalnej i Społecznej

Wydział Nauk Geograficznych Uniwersytet Łódzki e-mail: marcin.wojcik@geo.uni.lodz.pl 